\title{
Active $\mathrm{Ca}^{2+}$ reabsorption in the connecting tubule
}

\author{
Sandor Boros • René J. M. Bindels • \\ Joost G. J. Hoenderop
}

Received: 3 September 2008 / Accepted: 8 October 2008 / Published online: 7 November 2008

(C) The Author(s) 2008. This article is published with open access at Springerlink.com

\begin{abstract}
The kidney plays a crucial role in the maintenance of the body calcium $\left(\mathrm{Ca}^{2+}\right)$ balance. $\mathrm{Ca}^{2+}$ is an essential ion in all organisms and participates in a large variety of structural and functional processes. In mammals, active tubular $\mathrm{Ca}^{2+}$ reabsorption is restricted to the distal part of the nephron, i.e., the late distal convoluted (DCT2) and the connecting tubules (CNT), where approximately $10-15 \%$ of the total $\mathrm{Ca}^{2+}$ is reabsorbed. This active transcellular transport is hallmarked by the transient receptor potential vanilloid 5 (TRPV5) epithelial $\mathrm{Ca}^{2+}$ channel, regulated by an array of events, and mediated by hormones, including 1,25-dihydroxyvitamin $\mathrm{D}_{3}$, parathyroid hormone, and estrogen. Novel molecular mechanisms have been identified, such as the direct regulatory effects of klotho and tissue kallikrein on the abundance of TRPV5 at the apical membrane. The newly discovered mechanisms could provide potential pharmacological targets in the therapy of renal $\mathrm{Ca}^{2+}$ wasting. This review discusses the three basic molecular steps of active $\mathrm{Ca}^{2+}$ reabsorption in the DCT/CNT segments of the nephron, including apical entry, cytoplasmic transport, and basolateral extrusion of $\mathrm{Ca}^{2+}$. In addition, an overview of the recently identified mechanisms governing this active $\mathrm{Ca}^{2+}$ transport through the DCT2/CNT epithelial cells will be presented.
\end{abstract}

Keywords Transepithelial $\mathrm{Ca}^{2+}$ transport $\cdot$ TRPV5 $\cdot \mathrm{PTH}$. Vitamin D $\cdot$ Klotho $\cdot$ Calbindin

S. Boros $・$ R. J. M. Bindels · J. G. J. Hoenderop $(\bowtie)$ Department of Physiology (286), Nijmegen Centre for Molecular Life Sciences, Radboud University Nijmegen Medical Centre, P.O. Box 9101, Nijmegen $6500 \mathrm{HB}$, The Netherlands e-mail: j.hoenderop@ncmls.ru.nl

\section{Introduction}

Calcium $\left(\mathrm{Ca}^{2+}\right)$ is essential for the physiological functioning of all living cells. In humans, $99 \%$ of total body $\mathrm{Ca}^{2+}$ resides in the skeleton. The remaining $1 \%$ is distributed in soft tissues and extracellular fluid, which is the prime target of the $\mathrm{Ca}^{2+}$ homeostatic systems. Three tightly controlled mechanisms, including bone resorption and formation, intestinal absorption, and renal reabsorption, maintain $\mathrm{Ca}^{2+}$ homeostasis. In the kidney, approximately $45 \%$ of the plasma $\mathrm{Ca}^{2+}$, present in free ionized form, filters through the glomerulus and enters the proximal tubule segment of the nephron, where $\sim 65 \%$ of the filtered $\mathrm{Ca}^{2+}$ is passively reabsorbed [56, 62]. In the thick ascending loop of Henle (TAL), an additional $20 \%$ is reabsorbed through this passive paracellular pathway, mediated by the tight junction protein claudin-16 [3, 43]. In these segments, $\mathrm{Ca}^{2+}$ reabsorption is not specifically regulated and depends on gradients established by $\mathrm{NaCl}$ and water reabsorption [61]. The final regulation of $\mathrm{Ca}^{2+}$ excretion, according to physiological needs, appears to occur primarily in two segments of the distal part of the nephron, namely in the late part of the distal convoluted tubule (known as DCT2) and the connecting tubule (CNT; Table 1) [16].

\section{Morphologic characteristics of the CNT}

The above discussed distal segments of the nephron exhibit distinct morphological, as well as functional features. In the superficial cortex, the DCT/CNT region is short and flows directly into the cortical collecting duct (CCD). Midcortical and juxtamedullar nephrons, on the other hand, have longer DCT/CNTs merging with other CNT segments into arcades before transitioning to the CCD [56]. DCTs consist of two short segments, DCT1 and DCT2, both comprising a 
Table 1 Regulation of $\mathrm{Ca}^{2+}$ transporters

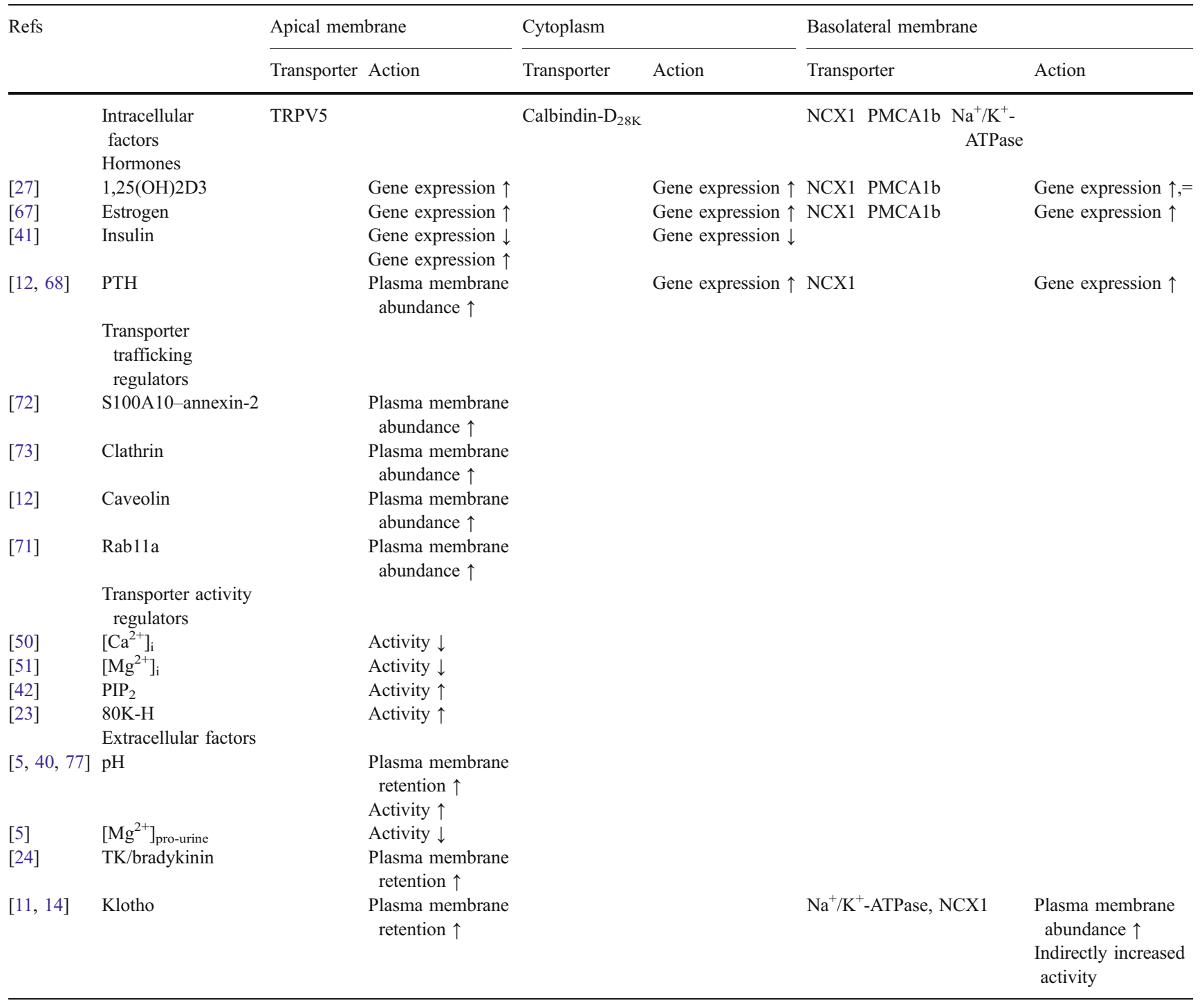

Regulation of $\mathrm{Ca}^{2+}$ transporters in kidney by intracellular and extracellular factors. Data included in the table were based on listed references $\uparrow$ increased gene expression, increased channel activity, or increased plasma membrane abundance, $\downarrow$ downregulation of gene expression or inhibition of channel activity, = no effect

uniform population of principal cells, whereas the CNT contains both principal and two types of intercalated cells [3, $16,43,56]$. Furthermore, the principal cells in the CNT have less cell-cell contacts and mitochondria, and their apical membrane contains fewer projections than DCT cells. Unlike the polygonal-shaped CNT cells, intercalated cells appear to be round with an apical membrane densely adorned with microprojections $[43,56]$. The proton secreting $\alpha$-intercalated cells have extensive apical microvilli with abundant expression of the $\mathrm{H}^{+} / \mathrm{K}^{+}$exchanger and vacuolar $\mathrm{H}^{+}$-ATPase and numerous subapically localized small mitochondria, whereas the bicarbonate secreting $\beta$-intercalated cells have fewer apical microvilli, and their mitochondria tend to accumulate basolaterally, where the proton pump is also located [56]. Although the ratio of $\alpha$ - and $\beta$-intercalated cells vary depending on the actual physiological state, $\alpha$ intercalated cells are more common in the CNT.

In addition to the ubiquitously expressed $\mathrm{Na}^{+} / \mathrm{K}^{+}$ATPase, the $\mathrm{Na}^{+} / \mathrm{Ca}^{2+}$ exchanger (NCX1) and the plasma membrane ATPase type 1b (PMCA1b) have been found along the DCT2/CNT region, whereas the apically localized thiazide-sensitive $\mathrm{Na}^{+} / \mathrm{Cl}^{-}$co-transporter (NCC) and the transient receptor potential melastin subtype 6 are present in the DCT (see Xi et al. in this issue). The DCT2 region also shares additional similarities with the CNT segment, as both segments express the transient receptor potential vanilloid type 5 (TRPV5) and the $\mathrm{Ca}^{2+}$-binding protein calbindin$\mathrm{D}_{28 \mathrm{~K}}$. The tight junctions in these segments are imperme- 
able for $\mathrm{Ca}^{2+}$, and transcellular $\mathrm{Ca}^{2+}$ transport occurs against an electrochemical gradient, supporting that $\mathrm{Ca}^{2+}$ reabsorption in the DCT2/CNT is mediated by active transepithelial transport.

\section{Transepithelial $\mathrm{Ca}^{2+}$ reabsorption}

Transepithelial transport of $\mathrm{Ca}^{2+}$ is a three-step process. It initiates with influx of $\mathrm{Ca}^{2+}$ across the apical membrane mediated by TRPV5 [29]. Subsequently, entered $\mathrm{Ca}^{2+}$ is sequestered by the specialized intracellular carrier protein calbindin- $\mathrm{D}_{28 \mathrm{~K}}$ and diffuses to the basolateral membrane (Fig. 1). Finally, transporter proteins, such as NCX1 and PMCA1b, extrude $\mathrm{Ca}^{2+}$ from the epithelial cell into the circulation (Fig. 1). The identification and characterization of TRPV5 as the gatekeeper of renal epithelial $\mathrm{Ca}^{2+}$ transport [30] gave new momentum to the understanding of the molecular mechanisms underlying the process of active $\mathrm{Ca}^{2+}$ reabsorption.
TRPV5- the apical gate

TRPV5, also known as the epithelial $\mathrm{Ca}^{2+}$ channel, is a member of the TRP channel superfamily [29]. This channel comprises large and flexible intracellular amino- and carboxyl-terminal tails flanking six transmembrane segments (TM) and an additional hydrophobic stretch between TM5 and TM6, predicted to be the pore-forming region. The amino-terminal tail contains six ankyrin repeats [19, 54] that are important structural elements for both channel assembly and protein-protein interactions [13, 19]. Furthermore, the first extracellular loop between TM1 and TM2 contains an evolutionary conserved asparagine $\left(\mathrm{N}_{358}\right)$ crucial for complex-glycosylation and in turn for regulating channel activity [11, 13, 33]. The carboxyl-terminal tail harbors three potential protein kinase $\mathrm{C}$ (PKC) sites, which suggests an important role for phosphorylation in channel activity. Moreover, in cultured mammalian cell systems, as well as in oocytes, TRPV5 is assembled into large homotetramers in order to acquire the active conformation

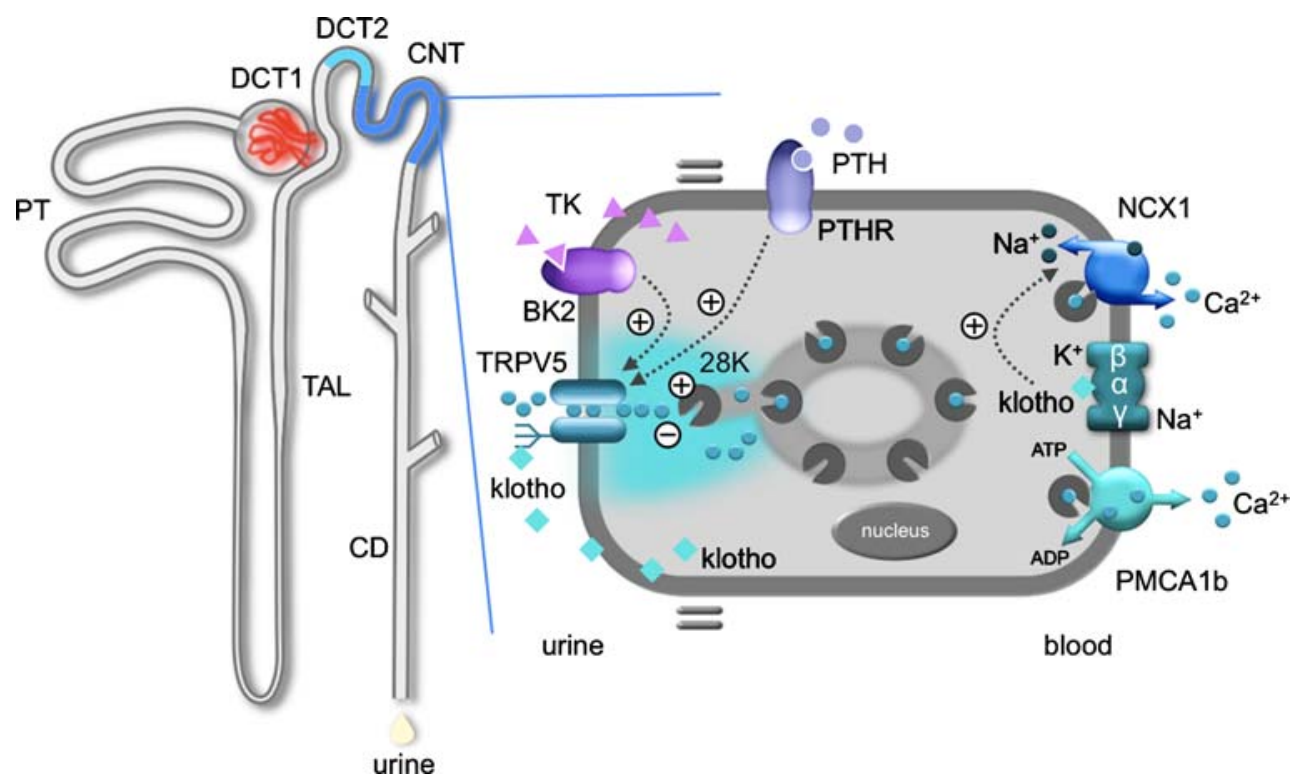

Fig. 1 Model of transcellular $\mathrm{Ca}^{2}$ reabsorption in DCT2 and CNT. The renal distal tubule in the nephron comprises anatomically discrete segments, including the thick ascending limb of the loop of Henle (TAL) and the distal convoluted tubule (DCT) that ends in the connecting tubule $(C N T)$. The late part of the DCT (DCT2) and CNT play an important role in fine-tuning renal excretion of $\mathrm{Ca}^{2+}$. The epithelial $\mathrm{Ca}^{2+}$ channel (TRPV5) is primarily expressed apically in these segments and co-localizes with calbindin-D $\mathrm{D}_{28 \mathrm{~K}}(28 \mathrm{~K}), \mathrm{Na}^{+} / \mathrm{Ca}^{2+}$ exchanger (NCXI), and the plasma membrane ATPase (PMCA1b). Upon entry via TRPV5, $\mathrm{Ca}^{2+}$ is buffered by $28 \mathrm{~K}$ and diffuses to the basolateral membrane, where it is released and extruded by a concerted action of NCX1 and PMCA1b. In addition, the basolateral membrane exposes a parathyroid hormone receptor $($ PTHR) and the
$\mathrm{Na}^{+} / \mathrm{K}^{+}$-ATPase consisting of the $\alpha$-, $\beta$ - and $\gamma$-subunit. PTHR activation by PTH stimulates TRPV5 activity, and entered $\mathrm{Ca}^{2+}$ can subsequently control the expression level of the $\mathrm{Ca}^{2+}$ transporters. At the apical membrane, there is a bradykinin receptor $(B K 2)$ that is activated by urinary tissue kallikrein $(T K)$ to activate TRPV5mediated $\mathrm{Ca}^{2+}$ influx. In the cell, entered $\mathrm{Ca}^{2+}$ acts as a negative feedback on channel activity, and $28 \mathrm{~K}$ plays a regulatory role by association with TRPV5 under low intracellular $\mathrm{Ca}^{2+}$ concentrations. Extracellular urinary klotho directly stimulates TRPV5 at the apical membrane by modification of the $N$-glycan, whereas intracellular klotho enhances $\mathrm{Na}^{+} / \mathrm{K}^{+}$-ATPase surface expression that in turn activates NCX1-mediated $\mathrm{Ca}^{2+}$ efflux 
state $[26,33]$. Facing each other, the hydrophobic stretches between TM5 and TM6 in each subunit are postulated to form the aqueous pore centered at the fourfold symmetry axis.

Detailed electrophysiological studies have compellingly demonstrated the constitutive activity of TRPV5 at low intracellular $\mathrm{Ca}^{2+}$ concentrations and physiological membrane potentials [75]. The current-voltage relationship of TRPV5 shows strong inward rectification [29, 74, 75]. Another important functional feature of TRPV5 is the high $\mathrm{Ca}^{2+}$ selectivity, making this epithelial $\mathrm{Ca}^{2+}$ channel the most $\mathrm{Ca}^{2+}$-selective member in the TRP superfamily [75]. Finally, the generation of a TRPV5 deficient mouse strain $\left(\mathrm{TRPV}^{-/-}\right.$) provided compelling evidence for the physiological function of this channel. Active $\mathrm{Ca}^{2+}$ reabsorption in DCT2 and CNT is severely impaired in these animals as $\mathrm{TRPV}^{-/-}$mice waste approximately six- to tenfold more $\mathrm{Ca}^{2+}$ than their wild-type littermates, which is in line with the postulated gatekeeper function of TRPV5 in active $\mathrm{Ca}^{2+}$ reabsorption [31].

Shortly after the identification of TRPV5, a homologous channel, sharing $75 \%$ amino acid identity with TRPV5, was cloned from intestine and named TRPV6 [53]. Although there are some functional differences between these channels, TRPV6 exhibits the same $\mathrm{Ca}^{2+}$ selectivity and current-voltage relationship [32, 47, 78]. Moreover, this latter channel has been implicated in intestinal $\mathrm{Ca}^{2+}$ absorption. Disturbances in the $\mathrm{Ca}^{2+}$ homeostasis were also reported in mice lacking TRPV6 $\left(\mathrm{TRPV}^{-1-}\right.$ ) as these animals display reduced intestinal $\mathrm{Ca}^{2+}$ absorption and low bone mineral density [1]. Although it has been shown that TRPV6 is moderately expressed in adult kidney [59] and the TRPV $6^{-1-}$ mice have increased urinary $\mathrm{Ca}^{2+}$ excretion, the exact role of TRPV6 in the kidney is not yet fully understood.

\section{Calbindin- $\mathrm{D}_{28 \mathrm{~K}}$ - the intracellular shuttle}

The principal cells of the DCT2/CNT segments are continuously challenged by a substantial $\mathrm{Ca}^{2+}$ influx through TRPV5, yet the cells manage to maintain a low intracellular $\mathrm{Ca}^{2+}$ concentration $\left(\left[\mathrm{Ca}^{2+}\right]_{\mathrm{i}}\right)$. Maintaining the free $\left[\mathrm{Ca}^{2+}\right]_{\mathrm{i}}$ at the basal level is essential for several reasons. High levels of free $\mathrm{Ca}^{2+}$ in the cytoplasm are known to induce apoptosis and protein precipitation. In addition, $\mathrm{Ca}^{2+}$ has an essential signaling function for many processes in the cell. More importantly, an increased $\left[\mathrm{Ca}^{2+}\right]_{\mathrm{i}}$ has been shown to inhibit the activity of TRPV5 [75]. Based on the currently available data, three different models have been postulated for transepithelial $\mathrm{Ca}^{2+}$ transfer from the apical to the basolateral membrane. The first model is based on a passive diffusion tunneling through the endoplasmatic reticulum, vesicular transport along the microtubules involving lysosomes, and finally, facilitated diffusion. According to the second model, $\mathrm{Ca}^{2+}$-transporting cells utilize lysosomes to sequester $\mathrm{Ca}^{2+}$ and facilitate its movement to the basolateral membrane [35]. The apical $\mathrm{Ca}^{2+}$ influx through TRPV5 initiates the disruption of the actin cytoskeleton and the formation of $\mathrm{Ca}^{2+}$-enriched endocytic vesicles, which are transported along the microtubules and some fuse with lysosomes [46]. In a third model, the intracellular diffusion of $\mathrm{Ca}^{2+}$ is facilitated by the vitamin $\mathrm{D}_{3}$-dependent $\mathrm{Ca}^{2+}$-binding protein, calbindin$\mathrm{D}_{28 \mathrm{~K}}$, in the principal cells of DCT2 and CNT segments [7, 20]. Together with parvalbumin, calmodulin, and troponin $\mathrm{C}$, calbindins are $\mathrm{Ca}^{2+}$-binding proteins that form a family of proteins with $\mathrm{Ca}^{2+}$ affinity [15]. Calbindin- $\mathrm{D}_{28 \mathrm{~K}}$ has three pairs of EF-hands that are the structural basis of the high $\mathrm{Ca}^{2+}$ affinity binding capacity [6]. Moreover, in the kidney, the expression of calbindin- $\mathrm{D}_{28 \mathrm{~K}}$ is restricted to DCT2, CNT, and CCD regions. It has also recently been shown that calbindin- $\mathrm{D}_{28 \mathrm{~K}}$ translocates to the TRPV5containing plasma membranes upon a decrease in intracellular $\left[\mathrm{Ca}^{2+}\right]$ and directly associates with this channel [39]. Due to the relatively slow $\mathrm{Ca}^{2+}$-binding kinetics of calbindin- $\mathrm{D}_{28 \mathrm{~K}}$, hormone-induced $\mathrm{Ca}^{2+}$ signaling can also occur independently of the transcellular $\mathrm{Ca}^{2+}$ transport rate [37]. Bound to calbindin- $\mathrm{D}_{28 \mathrm{~K}}, \mathrm{Ca}^{2+}$ is shuttled to the basolateral membrane, where $\mathrm{Ca}^{2+}$ is discharged into the blood flow by the basolateral $\mathrm{Ca}^{2+}$ extrusion systems. Finally, some studies reported that calbindin- $\mathrm{D}_{28 \mathrm{~K}}{ }^{-1-}$ mice fed a high $\mathrm{Ca}^{2+}$ diet have impaired renal $\mathrm{Ca}^{2+}$ handling as they excrete more $\mathrm{Ca}^{2+}$ in their urine than the wild-type control littermates [60], whereas other studies did not observe a difference that is probably due to the compensatory increase of renal calbindin- $\mathrm{D}_{9 \mathrm{~K}}$ expression [22]. These data suggest that calbindin- $\mathrm{D}_{28 \mathrm{~K}}$ facilitates the intracellular diffusion of $\mathrm{Ca}^{2+}$ in DCT2 and CNT.

\section{NCX1 and PMCA1b - the basolateral extrusion system}

The energy-consuming step of transcellular $\mathrm{Ca}^{2+}$ transport lies in the $\mathrm{Ca}^{2+}$ efflux process. In this step, intracellular $\mathrm{Ca}^{2}$ ${ }^{+}$is transported across the basolateral membrane against its electrochemical gradient, and the ions are extruded back to the blood flow. Two transporters have been implicated in this mechanism, PMCA1b and NCX1. Plasma membrane ATPases are high-affinity $\mathrm{Ca}^{2+}$ efflux pumps that maintain the resting $\mathrm{Ca}^{2+}$ concentration in virtually all cells [4]. The highest $\mathrm{Ca}^{2+}$-ATPase activity in kidney was reported in the DCT segment. However, earlier studies have suggested that the capacity of this PMCA pump in CNT seems to be insufficient to keep pace with the absorptive flux of $\mathrm{Ca}^{2+}$ because it can transport only $\sim 30 \%$ of the total $\mathrm{Ca}^{2+}$ efflux $[2,69]$. In contrast to PMCA1b, the $\mathrm{Na}^{+} / \mathrm{Ca}^{2+}$ exchanger has been shown to be a prerequisite for transepithelial $\mathrm{Ca}^{2+}$ 
transport $[2,69]$. NCX1 exchanges $\mathrm{Ca}^{2+}$ and $\mathrm{Na}^{+}$generally in a 1:3 stoichiometric ratio. Moreover, NCX1 is a widely expressed protein as it can be found in several tissues, including the heart, brain, and skeletal muscle [45]. In the kidney, the expression of NCX1 is restricted to the distal part of the nephron, particularly the CNT segment, where it predominantly localizes along the basolateral membrane [3, $28,43]$ and accounts for the remaining $70 \%$ of the $\mathrm{Ca}^{2+}$ efflux $[2,69]$.

\section{Regulatory mechanisms of $\mathrm{Ca}^{2+}$ transport in DCT2/ CNT}

The aforementioned transporters comprise the machinery transporting $\mathrm{Ca}^{2+}$ from pro-urine to the blood in the DCT2/ CNT. Several factors have been shown to contribute to the regulation of the $\mathrm{Ca}^{2+}$ transporting capacity of these particular nephron segments, which can be classified into four categories: (1) the control of the overall abundance of the transporter proteins by calciotropic hormones, (2) the rate of intracellular trafficking of the plasma membrane transporters, (3) alteration of activity of the transport proteins in the membrane by intracellular factors, and finally, (4) tuning apical $\mathrm{Ca}^{2+}$ influx by extracellular (luminal) factors.

Controlling the abundance of $\mathrm{Ca}^{2+}$ transporters

\section{PTH}

Parathyroid hormone (PTH) is an essential component of the $\mathrm{Ca}^{2+}$ homeostasis. The secretion of PTH from the parathyroid gland is triggered by changes in blood $\mathrm{Ca}^{2+}$ levels sensed by the parathyroid $\mathrm{Ca}^{2+}$-sensing receptor [8] PTH receptors have been detected in DCT2/CNT, enabling the direct control of active $\mathrm{Ca}^{2+}$ reabsorption by PTH [57].

PTH-mediated regulation of the $\mathrm{Ca}^{2+}$ transporters was studied in parathyroidectomized rats [68]. Parathyroidectomy reduced the expression of TRPV5, calbindin- $\mathrm{D}_{28 \mathrm{~K}}$, and NCX1. This decline in expression of $\mathrm{Ca}^{2+}$ transporters resulted in decreased active $\mathrm{Ca}^{2+}$ reabsorption and the development of hypocalcemia [68]. After PTH supplementation, the expression of $\mathrm{Ca}^{2+}$ transporters, as well as increased plasma $\mathrm{Ca}^{2+}$ concentration were normalized in these parathyroidectomized rats. In addition, the regulation by PTH was investigated in primary cultures of rabbit CNT cells. In these $\mathrm{Ca}^{2+}$-transporting cells, PTH resulted in an elevated expression of the $\mathrm{Ca}^{2+}$ transport proteins TRPV5, calbindin- $\mathrm{D}_{28 \mathrm{~K}}$, NCX1, and PMCA1b. Taken together, these results indicate that PTH stimulates renal $\mathrm{Ca}^{2+}$ handling by co-regulating the expression of the $\mathrm{Ca}^{2+}$ transport proteins [68]. In addition, experiments in these primary CNT cell cultures supported a gatekeeper role of
TRPV5 since a blockade of the apical $\mathrm{Ca}^{2+}$ influx by ruthenium red prevented the $\mathrm{PTH}$-induced upregulation of the other $\mathrm{Ca}^{2+}$ transporters.

\section{Vitamin D}

The vitamin $\mathrm{D}$ endocrine system plays a pivotal role in $\mathrm{Ca}^{2+}$ homeostasis. In the recent years, it has become clear that the active form of vitamin $\mathrm{D}$ (1,25-dihydroxyvitamin $\mathrm{D}_{3}$, or abbreviated $1,25(\mathrm{OH})_{2} \mathrm{D}_{3}$ ) is a potent regulator of the $\mathrm{Ca}^{2+}$ transport proteins. Several groups have shown transcriptional regulation of TRPV5, calbindin- $\mathrm{D}_{28 \mathrm{~K}}$, and NCX1 by $1,25(\mathrm{OH})_{2} \mathrm{D}_{3}$, whereas a $1,25(\mathrm{OH})_{2} \mathrm{D}_{3}$-sensitivity for PMCA1b is not consistently reported. Studies in vitaminD-deficient knockout models showed an impressive downregulation of renal TRPV5, calbindin- $\mathrm{D}_{28 \mathrm{~K}}$, and NCX1 mRNA that could be normalized by $1,25(\mathrm{OH})_{2} \mathrm{D}_{3}$ supplementation, whereas PMCA1b was not significantly affected [27]. On the other hand, several studies indicated that PMCA $1 b$ is positively regulated by $1,25(\mathrm{OH})_{2} \mathrm{D}_{3}$ in the intestine to increase $\mathrm{Ca}^{2+}$ absorption. Northern blot analysis indicated that repletion of vitamin-D-deficient chickens with vitamin D increases PMCA mRNAs in the duodenum, jejunum, ileum, and colon [9]. Because these studies and the role of vitamin $\mathrm{D}$ in $\mathrm{Ca}^{2+}$ homeostasis have been reviewed extensively [29, 64, 70], detailed information is not included in this review.

\section{Estrogen}

Although estrogen is generally not considered as a calciotropic hormone, it is widely accepted that it plays a role in renal $\mathrm{Ca}^{2+}$ handling. In rats, estradiol has been suggested to enhance the expression of TRPV5, NCX1, PMCA1b, and calbindin- $\mathrm{D}_{28 \mathrm{~K}}$ [67]. In line with these observations, a recent study with aromatase deficient mice lacking the aromatase enzyme (aromatase ${ }^{-1}$ ) and, therefore, estrogen deficient, also showed decreased expression of these transporters and concomitant renal $\mathrm{Ca}^{2+}$ wasting [52]. Additionally, estradiol treatment of these animals normalized the urinary $\mathrm{Ca}^{2+}$ excretion and gene expression. In agreement with these observations, increased renal $\mathrm{Ca}^{2+}$ wasting, as well as renal stone formation in women after menopause, is a well-known phenomenon [25], suggesting that estrogens may significantly contribute to the regulation of the transepithelial $\mathrm{Ca}^{2+}$ transport in the DCT2/CNT.

Controlling the intracellular trafficking

\section{S100A10/annexin-2}

S100A10 (also known as annexin-2 light chain) is an auxiliary protein for TRPV5 [72]. With two $\mathrm{Ca}^{2+}$. 
insensitive EF-hands, S100A10 is predominantly present as a heterotetrameric complex with annexin-2, which has been implicated in many cellular processes, including endocytosis and exocytosis [21]. An important regulatory role has been proposed for the S100A10-annexin-2 heteromer in TRPV5 functioning [72]. The binding of annexin-2 to TRPV5 through S100A10 was shown to facilitate the translocation of TRPV5 toward the plasma membrane. This association of S100A10 and TRPV5 takes place through a short conserved peptide sequence, located in the carboxyl-terminus of TRPV5. Moreover, co-expression of S100A10, annexin-2, and TRPV5 has been observed in DCT2/CNT [72]. Taken together, these findings show that the S100A10-annexin-2 complex is a significant component for trafficking of TRPV5 toward the plasma membrane.

\section{Rab11a}

The small GTPase Rab11a has also been identified as a novel TRPV5- associated protein [71]. Rab11a is one of the key regulatory proteins that controls the recycling of endosomes $[10,76]$. Rab11a was found to co-localize with TRPV5 in the DCT2/CNT. Here, both TRPV5 and Rab11a are present in subapical vesicular structures [71]. In addition, a direct protein-protein interaction was observed between Rab11a and TRPV5, suggesting that TRPV5 channels, present on the apical plasma membrane, recycle from the intracellular (recycling) endosomes in a Rab11dependent manner.

\section{Clathrin and caveolin}

Van de Graaf and coworkers observed that the extraction of TRPV5 from the cell surface takes place in a constitutive clathrin-dependent manner [73]. In addition, the same authors showed that following its internalization, TRPV5 is not immediately targeted to protein degradation. Instead, by entering a $\mathrm{Ca}^{2+}$-dependent recycling pathway, TRPV5 remained stable in the subapical endosomal fraction [73]. Another recent study by Huang et al. suggested a caveolin1-mediated internalization of TRPV5, which was inhibited by PKC [12]. Caveolin-1 is a structural component of caveolae and is crucial for the stabilization of the specialized membrane domains. Moreover, the caveolaedependent internalization of TRPV5 was strongly inhibited by PTH-induced phosphorylation of TRPV5 via PKC, indicating that next to its genetic effect on expression, PTH also has a rapid effect on channel abundance [12]. These findings indicate that apical sorting of TRPV5 is likely to be mediated by several mechanisms that could be differentially controlled depending on physiological needs of the body.
Regulation of TRPV5 activity at the membrane

Intracellular $\mathrm{Ca}^{2+}, \mathrm{Mg}^{2+}$, and $\mathrm{PIP}_{2}$

Although the $\mathrm{Ca}^{2+}$ concentration in the luminal compartment of DCT2/CNT is in the $1.0-1.5 \mathrm{mM}$ range, the resting $\left[\mathrm{Ca}^{2+}\right]_{\mathrm{i}}$ in these cells is maintained around $100 \mathrm{nM}$ by NCX1 and PMCA1b. TRPV5 has a high $\mathrm{Ca}^{2+}$ selectivity, and at physiological $\mathrm{Ca}^{2+}$ concentrations, its current is mainly carried by $\mathrm{Ca}^{2+}$. In human embryonic kidney (HEK293) cells heterogeneously expressing TRPV5, currents can be activated under conditions of high intracellular $\mathrm{Ca}^{2+}$ buffering by hyperpolarizing voltage steps. Earlier, Nilius et al. suggested that intracellular $\mathrm{Ca}^{2+}$ acts as a negative feedback switch regulating TRPV5 activity. The $\mathrm{Ca}^{2+}$ current through TRPV5 is inhibited by the $\left[\mathrm{Ca}^{2+}\right]_{\mathrm{i}}$ with an $\mathrm{IC}_{50}$ of $82 \mathrm{nM}$ [50]. Considering this high affinity of $\mathrm{Ca}^{2+}$-dependent channel inhibition, the presence of the co-expressed $\mathrm{Ca}^{2+}$ buffer calbindin in DCT2/CNT plays an important role to maintain TRPV5 activity. Conclusively, the $\left[\mathrm{Ca}^{2+}\right]_{\mathrm{i}}$ itself directly regulates channel function in order to maintain optimal $\mathrm{Ca}^{2+}$ reabsorption without excessive influx of $\mathrm{Ca}^{2+}$.

Single TRPV 5 channel currents in cell-attached and insideout patches were only detected in the absence of $\mathrm{Ca}^{2+}$ and had a conductance of $\sim 75 \mathrm{pS}$ [51]. So far, no reliable single channel measurements have been performed in the presence of extracellular $\mathrm{Ca}^{2+}$. Another interesting feature of TRPV5 is the open pore blockage by intracellular $\mathrm{Mg}^{2+}$. Currents through TRPV5 are small at physiological extracellular $\mathrm{Mg}^{2+}$ and $\mathrm{Ca}^{2+}$ concentrations, but sufficient to increase the $\left[\mathrm{Ca}^{2+}\right]_{\mathrm{i}}$ at hyperpolarized potentials. Therefore, block by $\mathrm{Mg}^{2+}$ and decrease of the current by extracellular $\mathrm{Ca}^{2+}$ might be physiologically important to prevent $\mathrm{Ca}^{2+}$ overload of TRPV5-expressing cells [51, 75]. In addition, Huang and colleagues reported that $\mathrm{PIP}_{2}$ activates TRPV5 and that activation of the channel by PIP $_{2}$ reduces the sensitivity of TRPV5 to the inhibition by the intracellular $\left[\mathrm{Mg}^{2+}\right][17,42]$. In this model, hydrolysis of $\mathrm{PIP}_{2}$ by receptor activation of PLC may increase the sensitivity for $\mathrm{Mg}^{2+}$ inhibition.

\section{$80 K-H$}

Another protein called $80 \mathrm{~K}-\mathrm{H}$ has been shown to directly interact with TRPV5 in a $\mathrm{Ca}^{2+}$-dependent manner [23]. The $80 \mathrm{~K}-\mathrm{H}$ protein contains two putative EF-hands and an ERtargeting signal. This TRPV5-linked protein was originally cloned as a PKC substrate and was subsequently associated with intracellular signaling [58]. Binding with $\mathrm{Ca}^{2+}$ abolished the inactivation of the two EF-hand motifs of $80 \mathrm{~K}-\mathrm{H}$, and this, in turn, reduced the TRPV5-mediated $\mathrm{Ca}^{2+}$ current and increased the sensitivity of TRPV5 to the $\left[\mathrm{Ca}^{2+}\right]_{\mathrm{i}}$, accelerating the feedback inhibition of the channel [23]. 
Moreover, 80K-H also co-localizes with TRPV5 in the DCT2/CNT. Based on these findings, $80 \mathrm{~K}-\mathrm{H}$ has been hypothesized to act a $\mathrm{Ca}^{2+}$ sensor to regulate the activity of TRPV5 at the plasma membrane [23].

Pro-urinary factors stabilize TRPV5 in the apical membrane

\section{Tissue kallikrein}

Tissue kallikrein (TK) is a multifunctional serine protease that is primarily synthesized in the DCT2 and CNT and catalyzes the kininogen kinin conversion [55]. TK is secreted into the pro-urine, where it mediates the formation of bradykinin that binds to the type 2 bradykinin receptor (B2R) [18]. A striking effect of TK has been observed in primary rabbit CNT cells mediating transcellular $\mathrm{Ca}^{2+}$ transport [24]. Apical addition of TK or bradykinin (BK) significantly increased transcellular $\mathrm{Ca}^{2+}$ transport that was prevented by $\mathrm{B} 2 \mathrm{R}$ antagonists, whereas basolateral application of either TK or BK had no effect [24]. This stimulatory effect of TK was mediated by the apical B2R signaling through the phospholipase $\mathrm{C} /$ diacylglycerol/PKC pathway, resulting in phosphorylation of TRPV5 and subsequent delay in its retrieval from the plasma membrane. Additionally, mice lacking $\mathrm{TK}\left(\mathrm{TK}^{-/}\right)$waste a large amount of $\mathrm{Ca}^{2+}$ without any significant alterations in plasma $\mathrm{Ca}^{2+}, \mathrm{PTH}$, and vitamin $\mathrm{D}_{3}$ levels or any detectable changes in the expression of $\mathrm{Ca}^{2+}$ transporters in the DCT2/ CNT. These observations together highlight the importance of the regulation of the TRPV5 channel abundance in the membrane by the pro-urine TK.

\section{Urinary $\mathrm{pH}$ and $\mathrm{Mg}^{2+}$}

The acid-base balance has long been known to affect $\mathrm{Ca}^{2+}$ homeostasis. For example, patients with chronic metabolic acidosis waste $\mathrm{Ca}^{2+}$. Pioneering micropuncture studies have shown that chronic metabolic acidosis results in $\mathrm{Ca}^{2+}$ wasting [63]. Recent advances in total reflection fluorescent microscopy analysis allowed the identification of the molecular basis underlying these in vivo observations. Exposure of TRPV5-expressing cells to an alkaline extracellular environment ( $\mathrm{pH}$ 8.0) caused rapid recruitment of TRPV5-containing vesicles to the cell surface and a consequent increase in TRPV5 activity [40]. In the reciprocal experiment, acidic extracellular milieu $(\mathrm{pH}$ 6.5) induced the internalization of TRPV5-containing vesicles from the plasma membrane, resulting in a reduced channel activity [40]. The extracellular acidity clearly affected the current kinetics resulting in diminished single channel conductance as shown by Yeh et al. [77]. Binding of protons to an extracellular glutamate near the pore helix of TRPV5 at position $522\left(\mathrm{E}_{522}\right)$ resulted in decreased channel activity, whereas substitution with a glutamine $\left(\mathrm{E}_{522} \rightarrow \mathrm{Q}_{522}\right)$ abolished the proton sensitivity. This recognized $\mathrm{E}_{522}$ as the extracellular $\mathrm{pH}$ sensor in TRPV5. Based on these experiments, binding of protons to the sensor has been proposed to induce a conformational change of the TRPV5 pore helix, leading to a lowered channel activity. These observations clearly point out that urinary acidification results in decreased channel activity at the apical cell membrane, as well as in a rapid retrieval of TRPV5 from the apical membrane, both of which are likely to account for the renal $\mathrm{Ca}^{2+}$ wasting in metabolic acidosis. Also, urinary $\mathrm{Mg}^{2+}$ is known to modulate urinary $\mathrm{Ca}^{2+}$ excretion, but the mechanism underlying this relationship is unknown. In a recent study by Bonny et al., it was elegantly demonstrated that an alteration in urinary $\mathrm{Ca}^{2+}$ excretion is directly proportional to the change in $\mathrm{Mg}^{2+}$ excretion and inversely proportional to the adjustment in urine $\mathrm{pH}$ [5]. Because TRPV5 was inhibited by $\mathrm{Mg}^{2+}$, these data are compatible with the hypothesis that urinary $\mathrm{Mg}^{2+}$ directly inhibits $\mathrm{Ca}^{2+}$ reabsorption in DCT2/CNT, which can be overruled by an alkaline luminal $\mathrm{pH}$.

\section{Klotho}

Klotho is a type-I (single-pass) membrane protein predominantly expressed in tissues involved in $\mathrm{Ca}^{2+}$ homeostasis, such as kidney, choroid plexus, and the parathyroid gland [34]. The ablation of klotho causes severe multiple phenotypes in klotho-deficient $\left(\mathrm{klotho}^{-/-}\right)$mice, such as short life span associated with infertility and sternly impaired $\mathrm{Ca}^{2+}$ and phosphate metabolism [38, 65]. There is a growing body of evidence that klotho controls active $\mathrm{Ca}^{2+}$ reabsorption in the DCT2/CNT segments through several mechanisms.

In kidney, klotho is exclusively expressed in DCT2/ CNT, where following extracellular domain shedding, it is secreted into the circulation and the pro-urine [13]. The secreted form of klotho exerts $\beta$-glucuronidase activity [14]. More importantly, klotho was suggested to regulate the apical entry of $\mathrm{Ca}^{2+}$ in the DCT2/CNT region. The presence of extracellular klotho robustly increased the activity of TRPV5 in cultured rabbit primary CNT cells. Moreover, TRPV5-expressing HEK293 cells also showed a significant rise in channel activity after klotho treatment that was accompanied with concomitant increased plasma membrane channel abundance [14]. In addition, removal of the complete $N$-glycan tree by Endo-F was recently reported to result in a more pronounced increase in TRPV5 activity compared to that of observed upon klotho treatment [44]. Recently, Cha et al. suggested sialidase rather than $\beta$ glucuronidase activity for klotho, as they observed a klotho-mediated removal of terminal sialic acids from the $N$-glycan in TRPV5 [11]. This cleavage exposed the 
underlying galactose- $N$-acetylglucoseamine disaccharides in TRPV5, which can directly interact with membranebound galectin-1, causing the subsequent plasma membrane retention of TRPV5. Interestingly, treatment with PNGaseF to hydrolyze the entire $N$-glycan of TRPV5 mimicked the stimulatory effect of klotho, suggesting additional mechanisms besides binding to membrane galectin-1. It should be noted that Cha et al. also reported a comparable increase in TRPV5 activity upon $\beta$-glucuronidase treatment; however, this effect could be observed only at much higher (0.1$1 \mu \mathrm{M})$ concentrations of the enzyme, suggesting that klotho exhibits primarily sialidase activity at physiologic concentrations $(\sim 20-200 \mathrm{pM})[11]$. These observations confirmed the original conclusion that extracellular klotho hydrolyses oligosaccharide chains from the $\mathrm{N}$-glycosylated TRPV5, causing channel retention at the membrane and a subsequent increase in TRPV5-mediated $\mathrm{Ca}^{2+}$ influx [14]. In line with these findings, microperfusion studies have shown that CNTs from klotho ${ }^{-/-}$mice fail to respond to PTH and, therefore, waste large amount of $\mathrm{Ca}^{2+}$ [66]. Interestingly, klotho was reported to interact and increase $\mathrm{Na}^{+} / \mathrm{K}^{+}$-ATPase activity at the plasma membrane and stimulating the $\mathrm{Na}^{+}$/ $\mathrm{Ca}^{2+}$ exchange through NCX1 [34]. Taken altogether, there is compelling evidence that klotho is a novel calciotropic factor that, amongst others, can exert its stimulatory effect on TRPV5 cell surface retention from the pro-urine in the DCT2 and the CNT.

\section{Clinical relevance}

Several clinical disorders, such as chronic renal failure or diabetes, are associated with the symptoms of dysregulating body $\mathrm{Ca}^{2+}$ homeostasis. Chronic renal failure (CRF) is frequently characterized by hypocalcemia, osteoporosis, growth retardation, and secondary hyperparathyroidism. Remarkably, the phenotype of the klotho ${ }^{-/-}$mice resembles most of these characteristics [36]. Moreover, CRF patients also have greatly reduced renal klotho levels [36]. Together with the fact that klotho can regulate the activity of TRPV5 and NCX1 via $\mathrm{Na}^{+} / \mathrm{K}^{+}$-ATPase, the involvement of klotho in the pathogenesis of $\mathrm{Ca}^{2+}$ abnormalities in CRF may be envisaged.

Hypercalciuria and nephrolithias, disorders with a high prevalence and socio-economic burden in the Western society, are often treated with thiazide diuretics. These drugs are known to affect the $\mathrm{Ca}^{2+}$ balance by inducing hypocalciuria. Over the last decade, it was speculated that thiazide-inhibited NCC activity stimulates active $\mathrm{Ca}^{2+}$ reabsorption in the DCT/CNT. However, recent studies indicated that paracellular $\mathrm{Ca}^{2+}$ transport in the proximal tubule due to extracellular volume contraction explains the hypocalciuria during chronic thiazide treatment [48, 49].
Hypercalciuria is also an early finding in diabetes mellitus patients. Similarly, rats with experimentally induced diabetes display a significant increase in the fractional excretion of $\mathrm{Ca}^{2+}$ [41]. However, these diabetic rats showed increased mRNA and protein levels of both TRPV5 and calbindin- $\mathrm{D}_{28 \mathrm{~K}}$. Additionally, insulin therapy corrected the hyperglycemia-associated hypercalciuria and abolished the upregulation of TRPV5, suggesting that the increased TRPV5 abundance in diabetic rats is due to a compensatory adaptation to an increased load of $\mathrm{Ca}^{2+}$ secondary to hyperglycemia. Although in many pathophysiological conditions the expression level of the $\mathrm{Ca}^{2+}$ transporters is out of balance, mutations in these proteins have not been discovered yet.

\section{Concluding remarks and future perspectives}

$\mathrm{Ca}^{2+}$ reabsorption in the kidney and particularly in the distal DCT2/CNT segments of the nephron is critical in the maintenance of the $\mathrm{Ca}^{2+}$ balance. Here, TRPV5 is the gatekeeper of the $\mathrm{Ca}^{2+}$ entry, and therefore, a tight control of its activity enables the organism to adjust $\mathrm{Ca}^{2+}$ reabsorption according to any demands of the body. The available experimental data summarized in this review highlights the most important mechanisms that can actually regulate active $\mathrm{Ca}^{2+}$ reabsorption. Of these, controlling the TRPV5 cell surface expression by extracellular factors in the pro-urine is a newly discovered mechanism. Klotho delays the retrieval of TRPV5 from the cell membrane by modifying the $N$ glycan composition, whereas the insertion of channels in the cell membrane is promoted by TK-induced phosphorylation or alkaline $\mathrm{pH}$. All mechanisms result in increased TRPV5 abundance and, in turn, regulate the entry of $\mathrm{Ca}^{2+}$ at the gate. However, the canvas is far from complete. The molecular mechanism by which intracellular $\mathrm{Ca}^{2+}$ bound to calbindin$\mathrm{D}_{28 \mathrm{~K}}$ is transported to the basolateral extrusion transporters NCX1 and PMCA1b is largely unknown. It could be envisaged that the local $\mathrm{Na}^{+}$concentration may promote the release of $\mathrm{Ca}^{2+}$; however, no experimental data are available to support this theory. Therefore, the $\mathrm{Ca}^{2+}$ transfer between calbindin- $\mathrm{D}_{28 \mathrm{~K}}$ on one site and NCX1 and PMCA1b on the other site needs special attention. Another interesting question to be solved is the regulation of the basolateral trafficking of NCX1 and PMCA1b in the DCT2 and CNT cells. Certain players, such as the scaffold 14-3-3, phospholemman, ankyrin, or caveolin-3, have been proposed to play a role in the trafficking of the NCX transporters in neurons and cardiac cells. Nevertheless, the basolateral sorting of these transporters in the DCT2/CNT is essentially unknown. Whether there is a crosstalk between the apical $\mathrm{Ca}^{2+}$ entry and the basolateral $\mathrm{Ca}^{2+}$ extrusion regulatory apparatus is not known. The fact that klotho increases both 
the channel abundance of TRPV5 in the apical membrane and the activity of NCX1 at the basolateral side certainly predicts the existence of such crosstalk [14, 34]. The main question for the coming years is how all of these $\mathrm{Ca}^{2+}$ transport proteins communicate with each other in order to facilitate optimal and regulated transcellular $\mathrm{Ca}^{2+}$ reabsorption in DCT2 and CNT under conditions of disturbed $\mathrm{Ca}^{2+}$ homeostasis.

Acknowledgments This work was financially supported in part by grants from the Dutch Kidney Foundation (C03.6017, C06.2170), the Netherlands Organization for Scientific Research (NWO-ALW 814.02.001, NWO-CW 700.55.302, ZonMw 9120.6110). J. Hoenderop is supported by an EURYI award.

Open Access This article is distributed under the terms of the Creative Commons Attribution Noncommercial License which permits any noncommercial use, distribution, and reproduction in any medium, provided the original author(s) and source are credited.

\section{References}

1. Bianco SD, Peng JB, Takanaga H, Suzuki Y, Crescenzi A, Kos $\mathrm{CH}$, Zhuang L, Freeman MR, Gouveia CH, Wu J, Luo H, Mauro T, Brown EM, Hediger MA (2007) Marked disturbance of calcium homeostasis in mice with targeted disruption of the Trpv6 calcium channel gene. J Bone Miner Res 22:274-285

2. Bindels RJ, Ramakers PL, Dempster JA, Hartog A, van $\mathrm{Os} \mathrm{CH}$ (1992) Role of $\mathrm{Na}^{+} / \mathrm{Ca}^{2+}$ exchange in transcellular $\mathrm{Ca}^{2+}$ transport across primary cultures of rabbit kidney collecting system. Pflugers Arch 420:566-572

3. Biner HL, Arpin-Bott MP, Loffing J, Wang X, Knepper M, Hebert SC, Kaissling B (2002) Human cortical distal nephron: distribution of electrolyte and water transport pathways. J Am Soc Nephrol 13:836-847

4. Blaustein MP, Juhaszova M, Golovina VA, Church PJ, Stanley EF (2002) $\mathrm{Na} / \mathrm{Ca}$ exchanger and PMCA localization in neurons and astrocytes: functional implications. Ann N Y Acad Sci 976:356-366

5. Bonny O, Rubin A, Huang CL, Frawley WH, Pak CY, Moe OW (2008) Mechanism of urinary calcium regulation by urinary magnesium and $\mathrm{pH}$. J Am Soc Nephrol 19:1530-1537

6. Bouhtiauy I, Lajeunesse D, Christakos S, Brunette MG (1994) Two vitamin $\mathrm{D}_{3}$-dependent calcium binding proteins increase calcium reabsorption by different mechanisms. I. Effect of CaBP28K. Kidney Int 45:461-468

7. Bronner F (1989) Renal calcium transport: mechanisms and regulation - an overview. Am J Physiol 257:F707-711

8. Brown EM, Gamba G, Riccardi D, Lombardi M, Butters R, Kifor O, Sun A, Hediger MA, Lytton J, Hebert SC (1993) Cloning and characterization of an extracellular $\mathrm{Ca}^{2+}$-sensing receptor from bovine parathyroid. Nature 366:575-580

9. Cai Q, Chandler JS, Wasserman RH, Kumar R, Penniston JT (1993) Vitamin D and adaptation to dietary calcium and phosphate deficiencies increase intestinal plasma membrane calcium pump gene expression. Proc Natl Acad Sci USA 90:1345-1349

10. Casanova JE, Wang X, Kumar R, Bhartur SG, Navarre J, Woodrum JE, Altschuler Y, Ray GS, Goldenring JR (1999) Association of Rab25 and Rab11a with the apical recycling system of polarized Madin-Darby canine kidney cells. Mol Biol Cell 10:47-61
11. Cha SK, Ortega B, Kurosu H, Rosenblatt KP, Kuro-o M, Huang CL (2008) Removal of sialic acid involving Klotho causes cellsurface retention of TRPV5 channel via binding to galectin-1. Proc Natl Acad Sci USA 105:9805-9810

12. Cha SK, Wu T, Huang CL (2008) Protein kinase C inhibits caveolae-mediated endocytosis of TRPV5. Am J Physiol Renal Physiol 294:F1212-F1221

13. Chang Q, Gyftogianni E, van de Graaf SF, Hoefs S, Weidema FA, Bindels RJ, Hoenderop JG (2004) Molecular determinants in TRPV5 channel assembly. J Biol Chem 279:54304-54311

14. Chang Q, Hoefs S, van der Kemp AW, Topala CN, Bindels RJ, Hoenderop JG (2005) The beta-glucuronidase klotho hydrolyzes and activates the TRPV5 channel. Science 310:490-493

15. Christakos S, Gabrielides C, Rhoten WB (1989) Vitamin Ddependent calcium binding proteins: chemistry, distribution, functional considerations, and molecular biology. Endocr Rev 10:3-26

16. Costanzo LS, Windhager EE, Ellison DH (2000) Calcium and sodium transport by the distal convoluted tubule of the rat. 1978. J Am Soc Nephrol 11:1562-1580

17. Dodier Y, Banderali U, Klein H, Topalak O, Dafi O, Simoes M, Bernatchez G, Sauve R, Parent L (2004) Outer pore topology of the ECaC-TRPV5 channel by cysteine scan mutagenesis. J Biol Chem 279:6853-6862

18. Erdos EG, Deddish PA (2002) The kinin system: suggestions to broaden some prevailing concepts. Int Immunopharmacol 2:17411746

19. Erler I, Hirnet D, Wissenbach U, Flockerzi V, Niemeyer BA (2004) $\mathrm{Ca}^{2+}$-selective transient receptor potential V channel architecture and function require a specific ankyrin repeat. J Biol Chem 279:34456-34463

20. Feher JJ (1983) Facilitated calcium diffusion by intestinal calcium-binding protein. Am J Physiol 244:C303-307

21. Gerke V, Creutz CE, Moss SE (2005) Annexins: linking $\mathrm{Ca}^{2+}$ signalling to membrane dynamics. Nat Rev Mol Cell Biol 6:449461

22. Gkika D, Hsu YJ, van der Kemp AW, Christakos S, Bindels RJ, Hoenderop JG (2006) Critical role of the epithelial $\mathrm{Ca}^{2+}$ channel TRPV5 in active $\mathrm{Ca}^{2+}$ reabsorption as revealed by TRPV5/ calbindin- $\mathrm{D}_{28 \mathrm{~K}}$ knockout mice. J Am Soc Nephrol 17:3020-3027

23. Gkika D, Mahieu F, Nilius B, Hoenderop JG, Bindels RJ (2004) $80 \mathrm{~K}-\mathrm{H}$ as a new $\mathrm{Ca}^{2+}$ sensor regulating the activity of the epithelial $\mathrm{Ca}^{2+}$ channel transient receptor potential cation channel V5 (TRPV5). J Biol Chem 279:26351-26357

24. Gkika D, Topala CN, Chang Q, Picard N, Thebault S, Houillier P, Hoenderop JG, Bindels RJ (2006) Tissue kallikrein stimulates $\mathrm{Ca}^{2+}$ reabsorption via PKC-dependent plasma membrane accumulation of TRPV5. Embo J 25:4707-4716

25. Heller HJ, Sakhaee K, Moe OW, Pak CY (2002) Etiological role of estrogen status in renal stone formation. J Urol 168:1923-1927

26. Hellwig N, Albrecht N, Harteneck C, Schultz G, Schaefer M (2005) Homo- and heteromeric assembly of TRPV channel subunits. J Cell Science 118:917-928

27. Hoenderop JG, Dardenne O, Van Abel M, Van Der Kemp AW, Van Os CH, St-Arnaud R, Bindels RJ (2002) Modulation of renal $\mathrm{Ca}^{2+}$ transport protein genes by dietary $\mathrm{Ca}^{2+}$ and 1,25-dihydroxyvitamin $\mathrm{D}_{3}$ in 25-hydroxyvitamin $\mathrm{D}_{3}$-1alpha-hydroxylase knockout mice. Faseb J 16:1398-1406

28. Hoenderop JG, Hartog A, Stuiver M, Doucet A, Willems PH, Bindels RJ (2000) Localization of the epithelial $\mathrm{Ca}^{2+}$ channel in rabbit kidney and intestine. J Am Soc Nephrol 11:1171-1178

29. Hoenderop JG, Nilius B, Bindels RJ (2005) Calcium absorption across epithelia. Physiol Rev 85:373-422

30. Hoenderop JG, van der Kemp AW, Hartog A, van de Graaf SF, van Os CH, Willems PH, Bindels RJ (1999) Molecular identification of the apical $\mathrm{Ca}^{2+}$ channel in 1,25-dihydroxyvitamin $\mathrm{D}_{3}$ responsive epithelia. J Biol Chem 274:8375-8378 
31. Hoenderop JG, van Leeuwen JP, van der Eerden BC, Kersten FF, van der Kemp AW, Merillat AM, Waarsing JH, Rossier BC, Vallon V, Hummler E, Bindels RJ (2003) Renal $\mathrm{Ca}^{2+}$ wasting, hyperabsorption, and reduced bone thickness in mice lacking TRPV5. J Clin Invest 112:1906-1914

32. Hoenderop JG, Vennekens R, Muller D, Prenen J, Droogmans G, Bindels RJ, Nilius B (2001) Function and expression of the epithelial $\mathrm{Ca}^{2+}$ channel family: comparison of mammalian $\mathrm{ECaC} 1$ and 2. J Physiol 537:747-761

33. Hoenderop JG, Voets T, Hoefs S, Weidema F, Prenen J, Nilius B, Bindels RJ (2003) Homo- and heterotetrameric architecture of the epithelial $\mathrm{Ca}^{2+}$ channels TRPV5 and TRPV6. Embo J 22:776-785

34. Imura A, Tsuji Y, Murata M, Maeda R, Kubota K, Iwano A, Obuse C, Togashi K, Tominaga M, Kita N, Tomiyama K, Iijima J, Nabeshima Y, Fujioka M, Asato R, Tanaka S, Kojima K, Ito J, Nozaki K, Hashimoto N, Ito T, Nishio T, Uchiyama T, Fujimori T, Nabeshima Y (2007) alpha-Klotho as a regulator of calcium homeostasis. Science 316:1615-1618

35. Khanal RC, Nemere I (2008) Regulation of intestinal calcium transport. Annu Rev Nutr 28:179-196

36. Koh N, Fujimori T, Nishiguchi S, Tamori A, Shiomi S, Nakatani T, Sugimura K, Kishimoto T, Kinoshita S, Kuroki T, Nabeshima Y (2001) Severely reduced production of klotho in human chronic renal failure kidney. Biochem Biophys Res Commun 280:1015-1020

37. Koster HP, Hartog A, Van Os CH, Bindels RJ (1995) Calbindin$\mathrm{D}_{28 \mathrm{~K}}$ facilitates cytosolic calcium diffusion without interfering with calcium signaling. Cell Calcium 18:187-196

38. Kuro-o M (2000) Introduction: aging research comes of age. Cell Mol Life Sci 57:695-697

39. Lambers TT, Mahieu F, Oancea E, Hoofd L, de Lange F, Mensenkamp AR, Voets T, Nilius B, Clapham DE, Hoenderop JG, Bindels RJ (2006) Calbindin- $\mathrm{D}_{28 \mathrm{~K}}$ dynamically controls TRPV5-mediated $\mathrm{Ca}^{2+}$ transport. Embo J 25:2978-2988

40. Lambers TT, Oancea E, de Groot T, Topala CN, Hoenderop JG, Bindels RJ (2007) Extracellular pH dynamically controls cell surface delivery of functional TRPV5 channels. Mol Cell Biol 27:1486-1494

41. Lee CT, Lien YH, Lai LW, Chen JB, Lin CR, Chen HC (2006) Increased renal calcium and magnesium transporter abundance in streptozotocin-induced diabetes mellitus. Kidney Int 69:1786-1791

42. Lee J, Cha SK, Sun TJ, Huang CL (2005) PIP2 activates TRPV5 and releases its inhibition by intracellular $\mathrm{Mg}^{2+}$. J Gen Physiol 126:439-451

43. Loffing J, Loffing-Cueni D, Valderrabano V, Klausli L, Hebert SC, Rossier BC, Hoenderop JG, Bindels RJ, Kaissling B (2001) Distribution of transcellular calcium and sodium transport pathways along mouse distal nephron. Am J Physiol Renal Physiol 281:F1021-1027

44. Lu P, Boros S, Chang Q, Bindels RJ, Hoenderop JG (2008) The \{beta\}-glucuronidase klotho exclusively activates the epithelial $\mathrm{Ca}^{2+}$ channels TRPV5 and TRPV6. Nephrol Dial Transplant 23 (11):3397-3402

45. Lytton $J$ (2007) $\mathrm{Na}^{+} / \mathrm{Ca}^{2+}$ exchangers: three mammalian gene families control $\mathrm{Ca}^{2+}$ transport. Biochem J 406:365-382

46. Nemere I, Norman AW (1988) 1,25-Dihydroxyvitamin $D_{3}$ mediated vesicular transport of calcium in intestine: time-course studies. Endocrinology 122:2962-2969

47. Niemeyer BA, Bergs C, Wissenbach U, Flockerzi V, Trost C (2001) Competitive regulation of CaT-like-mediated $\mathrm{Ca}^{2+}$ entry by protein kinase $\mathrm{C}$ and calmodulin. Proc Natl Acad Sci USA 98:3600-3605

48. Nijenhuis T, Hoenderop JG, Bindels RJ (2005) TRPV5 and TRPV6 in $\mathrm{Ca}^{2+}$ (re)absorption: regulating $\mathrm{Ca}^{2+}$ entry at the gate. Pflugers Arch 451:181-192

49. Nijenhuis T, Vallon V, van der Kemp AW, Loffing J, Hoenderop JG, Bindels RJ (2005) Enhanced passive $\mathrm{Ca}^{2+}$ reabsorption and reduced $\mathrm{Mg}^{2+}$ channel abundance explains thiazide-induced hypocalciuria and hypomagnesemia. J Clin Invest 115:1651-1658

50. Nilius B, Prenen J, Vennekens R, Hoenderop JG, Bindels RJ, Droogmans G (2001) Modulation of the epithelial calcium channel, $\mathrm{ECaC}$, by intracellular $\mathrm{Ca}^{2+}$. Cell Calcium 29:417-428

51. Nilius B, Vennekens R, Prenen J, Hoenderop JG, Bindels RJ, Droogmans G (2000) Whole-cell and single channel monovalent cation currents through the novel rabbit epithelial $\mathrm{Ca}^{2+}$ channel ECaC. J Physiol 527(Pt 2):239-248

52. Oz OK, Hajibeigi A, Howard K, Cummins CL, van Abel M, Bindels RJ, Word RA, Kuro-o M, Pak CY, Zerwekh JE (2007) Aromatase deficiency causes altered expression of molecules critical for calcium reabsorption in the kidneys of female mice. $\mathrm{J}$ Bone Miner Res 22:1893-1902

53. Peng JB, Chen XZ, Berger UV, Vassilev PM, Tsukaguchi $H$, Brown EM, Hediger MA (1999) Molecular cloning and characterization of a channel-like transporter mediating intestinal calcium absorption. J Biol Chem 274:22739-22746

54. Phelps CB, Huang RJ, Lishko PV, Wang RR, Gaudet R (2008) Structural analyses of the ankyrin repeat domain of TRPV6 and related TRPV ion channels. Biochemistry 47:2476-2484

55. Proud D, Knepper MA, Pisano JJ (1983) Distribution of immunoreactive kallikrein along the rat nephron. Am J Physiol 244:F510-F515

56. Reilly RF, Ellison DH (2000) Mammalian distal tubule: physiology, pathophysiology, and molecular anatomy. Physiol Rev 80:277-313

57. Riccardi D, Lee WS, Lee K, Segre GV, Brown EM, Hebert SC (1996) Localization of the extracellular $\mathrm{Ca}^{2+}$-sensing receptor and PTH/PTHrP receptor in rat kidney. Am J Physiol 271:F951956

58. Sakai K, Hirai M, Minoshima S, Kudoh J, Fukuyama R, Shimizu $\mathrm{N}$ (1989) Isolation of cDNAs encoding a substrate for protein kinase $\mathrm{C}$ : nucleotide sequence and chromosomal mapping of the gene for a human $80 \mathrm{~K}$ protein. Genomics 5:309-315

59. Song Y, Peng X, Porta A, Takanaga H, Peng JB, Hediger MA, Fleet JC, Christakos S (2003) Calcium transporter 1 and epithelial calcium channel messenger ribonucleic acid are differentially regulated by 1,25 dihydroxyvitamin $\mathrm{D}_{3}$ in the intestine and kidney of mice. Endocrinology 144:3885-3894

60. Sooy K, Schermerhorn T, Noda M, Surana M, Rhoten WB, Meyer M, Fleischer N, Sharp GW, Christakos S (1999) Calbindin-D(28k) controls $\left[\mathrm{Ca}^{2+}\right] \mathrm{i}$ and insulin release. Evidence obtained from calbindin-d(28k) knockout mice and beta cell lines. J Biol Chem 274:34343-34349

61. Suki WN (1979) Calcium transport in the nephron. Am J Physiol 237:F1-F6

62. Sutton RA, Dirks JH (1975) The renal excretion of calcium: a review of micropuncture data. Can J Physiol Pharmacol 53:979988

63. Sutton RA, Wong NL, Dirks JH (1979) Effects of metabolic acidosis and alkalosis on sodium and calcium transport in the dog kidney. Kidney Int 15:520-533

64. Suzuki Y, Landowski CP, Hediger MA (2008) Mechanisms and regulation of epithelial $\mathrm{Ca}^{2+}$ absorption in health and disease. Ann Rev Physiol 70:257-271

65. Tsujikawa H, Kurotaki Y, Fujimori T, Fukuda K, Nabeshima Y (2003) Klotho, a gene related to a syndrome resembling human premature aging, functions in a negative regulatory circuit of vitamin D endocrine system. Mol Endocrinol 17:2393-2403

66. Tsuruoka S, Nishiki K, Ioka T, Ando H, Saito Y, Kurabayashi M, Nagai R, Fujimura A (2006) Defect in parathyroid-hormoneinduced luminal calcium absorption in connecting tubules of Klotho mice. Nephrol Dial Transplant 21:2762-2767

67. Van Abel M, Hoenderop JG, Dardenne O, St Arnaud R, Van Os CH, Van Leeuwen HJ, Bindels RJ (2002) 1,25-Dihydroxyvitamin 
$\mathrm{D}_{3}$-independent stimulatory effect of estrogen on the expression of ECaC1 in the kidney. J Am Soc Nephrol 13:2102-2109

68. van Abel M, Hoenderop JG, van der Kemp AW, Friedlaender MM, van Leeuwen JP, Bindels RJ (2005) Coordinated control of renal $\mathrm{Ca}^{2+}$ transport proteins by parathyroid hormone. Kidney Int 68:1708-1721

69. Van Baal J, Yu A, Hartog A, Fransen JA, Willems PH, Lytton J, Bindels RJ (1996) Localization and regulation by vitamin D of calcium transport proteins in rabbit cortical collecting system. Am J Physiol 271:F985-F993

70. van de Graaf SF, Bindels RJ, Hoenderop JG (2007) Physiology of epithelial $\mathrm{Ca}^{2+}$ and $\mathrm{Mg}^{2+}$ transport. Rev Physiol, Biochem Pharmacol 158:77-160

71. van de Graaf SF, Chang Q, Mensenkamp AR, Hoenderop JG, Bindels RJ (2006) Direct interaction with Rab11a targets the epithelial $\mathrm{Ca}^{2+}$ channels TRPV5 and TRPV6 to the plasma membrane. Mol Cell Biol 26:303-312

72. van de Graaf SF, Hoenderop JG, Gkika D, Lamers D, Prenen J, Rescher U, Gerke V, Staub O, Nilius B, Bindels RJ (2003) Functional expression of the epithelial $\mathrm{Ca}^{2+}$ channels (TRPV5 and TRPV6) requires association of the S100A10-annexin 2 complex. Embo J 22:1478-1487
73. van de Graaf SF, Rescher U, Hoenderop JG, Verkaart S, Bindels RJ, Gerke V (2008) TRPV5 is internalized via clathrin-dependent endocytosis to enter a $\mathrm{Ca}^{2+}$-controlled recycling pathway. J Biol Chem 283:4077-4086

74. Vassilev PM, Peng JB, Hediger MA, Brown EM (2001) Singlechannel activities of the human epithelial $\mathrm{Ca}^{2+}$ transport proteins CaT1 and CaT2. J Membr Biol 184:113-120

75. Vennekens R, Hoenderop JG, Prenen J, Stuiver M, Willems PH, Droogmans G, Nilius B, Bindels RJ (2000) Permeation and gating properties of the novel epithelial $\mathrm{Ca}^{2+}$ channel. J Biol Chem 275:3963-3969

76. Wang X, Kumar R, Navarre J, Casanova JE, Goldenring JR (2000) Regulation of vesicle trafficking in madin-darby canine kidney cells by Rab11a and Rab25. J Biol Chem 275:2913829146

77. Yeh BI, Sun TJ, Lee JZ, Chen HH, Huang CL (2003) Mechanism and molecular determinant for regulation of rabbit transient receptor potential type 5 (TRPV5) channel by extracellular $\mathrm{pH}$. J Biol Chem 278:51044-51052

78. Yue L, Peng JB, Hediger MA, Clapham DE (2001) CaT1 manifests the pore properties of the calcium-release-activated calcium channel. Nature 410:705-709 